Article

\title{
Grazing Intensity Impacts on Herbage Mass, Sward Structure, Greenhouse Gas Emissions, and Animal Performance: Analysis of Brachiaria Pastureland
}

\author{
Ana Cláudia Ruggieri ${ }^{1}$, Abmael da Silva Cardoso ${ }^{1, *} \mathbb{0}$, Fernando Ongaratto ${ }^{1}$, \\ Daniel Rume Casagrande ${ }^{2}$, Rondineli Pavezzi Barbero ${ }^{3}{ }^{-0}$, Liziane de Figueiredo Brito ${ }^{1}$, \\ Mariane Vieira Azenha ${ }^{4}$, André Alves Oliveira ${ }^{5}$, Jefferson Fabiano Werner Koscheck ${ }^{5}$ \\ and Ricardo Andrade Reis ${ }^{1}$ \\ 1 Departamento de Zootecnia, Faculdade de Ciências Agrárias e Veterinárias, Campus Jaboticabal, \\ Universidade Estadual Paulista, Via de Acesso Prof. Paulo Donato Castellane, Jaboticabal, \\ São Paulo 14884-900, Brazil; ana.ruggieri@unesp.br (A.C.R.); fernandoongaratto@hotmail.com (F.O.); \\ lizianefb@gmail.com (L.d.F.B.); ricardo.reis@unesp.br (R.A.R.) \\ 2 Departamento de Zootecnia, Campus Lavras, Universidade Federal de Lavras, Lavras, \\ Minas Gerais 37200-000, Brazil; danielcasagrande@dzo.ufla.br \\ 3 Departamento de Produção Animal, Instituo de Zootecnia, Campos Seropédica, Universidade Federal Rural \\ do Rio de Janeiro, Rodovia BR 465, Km 07, Seropédica, Rio de Janeiro 23890-000, Brazil; \\ rondinelibarbero@zootecnista.com.br \\ 4 Premix, Rua Milton José Robusti, n 75, 17 Andar, Jardim Botânico, Ribeirão Preto, \\ São Paulo 14021-613, Brazil; maryazenha@hotmail.com \\ 5 Trouw Nutrition, Av. José Rocha Bonfim, 214, Campinas, São Paulo 13080-650, Brazil; \\ andre.oliveira@trouwnutrition.com (A.A.O.); jefferson.koscheck@trouwnutrition.com (J.F.W.K.) \\ * Correspondence: abmael.cardoso@unesp.br; Tel.: +55-016-99700-3447
}

Received: 25 September 2020; Accepted: 4 November 2020; Published: 11 November 2020

\begin{abstract}
A 7 year experiment (2008-2014) evaluated cattle grazing intensity (sward height) effects on herbage mass, forage quality, and greenhouse gas emissions in continuously stocked pastures containing the tropical 'Marandu' palisade grass (Brachiaria brizantha (Hochst. ex A. Rich) Stapf cv. Marandu). The experiment consisted of three sward height treatments $(15,25$, and $35 \mathrm{~cm})$ and six replicates. There were four periods each year during the rearing phase. Significant effects were found for herbage mass, proportions of leaf and stem, crude protein, neutral detergent fiber, acid detergent fiber, lignin, animal performance, enteric methane $\left(\mathrm{CH}_{4}\right)$, and greenhouse gas (GHG) emissions from soils. When the canopy height increased from 15 to $35 \mathrm{~cm}$, the herbage mass rose from 5.23 to $9.86 \mathrm{~kg} \mathrm{tha}^{-1}$, leaf percentage decreased, and stem percentage increased. Crude protein content averaged $14.2 \%$, and neutral detergent fiber averaged $58 \%$. Average daily gain averaged $0.67,0.81$, and $0.90 \mathrm{~kg}^{-1}$ head $^{-1}$, while live weight gain ha ${ }^{-1}$ was 649,530 , and $439 \mathrm{~kg}$ for the 15,25 , and $35 \mathrm{~cm}$ treatments, respectively. The weather variables explained the GHG emissions, interannual herbage mass, and structure variations.
\end{abstract}

Keywords: beef cattle; tropical pasture; Marandu grass; continuous stocking

\section{Introduction}

Beef cattle production is an important source of protein, minerals, and vitamins for human nutrition. However, it requires significant quantities of natural resources and may negatively impact the environment through greenhouse gas (GHG) emissions [1-3]. Beef cattle production is pasture-based 
in tropical regions, but tropical grasses usually have low crude protein $(\mathrm{CP})$, and high neutral detergent fiber (NDF) and acid detergent fiber (ADF) concentrations, which lead to lower animal performance and greater enteric methane $\left(\mathrm{CH}_{4}\right)$ emissions [2,4].

The genus Brachiaria (syn. Urochloa) has been extensively cultivated in tropical regions. In Brazil, more than 100 million hectares are cultivated with Brachiaria, mainly 'Marandu' (Brachiaria brizantha (Hochst. ex A. Rich) Stapf.). Brachiaria species account for $60 \%$ of the Brazilian market for forage seeds and $90 \%$ of exported seeds [5]. Reasons for the success of Brachiaria are the adaptation and persistence of these grasses in soils with low $\mathrm{pH}$ associated aluminum toxicity, phosphorus (P) deficiency, and low soil organic matter [6]. Therefore, this study investigated the Marandu palisade grass cultivar in a long-term study.

According to several studies, the Marandu palisade grass sward heights used in rotational grazing are $30 \mathrm{~cm}$ to put the animals and $15 \mathrm{~cm}$ to remove the animals [7-10]. These studies revealed that nutritive value decreases above $30 \mathrm{~cm}$, and regrowth declines below $15 \mathrm{~cm}$. Usually, the adoption of pasture height that represents $95 \%$ of light interception results in a greater green leaf proportion, $\mathrm{CP}$, lesser dead material, and neutral detergent fiber (NDF) during the growing season [10]. Pasture height also affects grazing behavior [2]. Dry matter intake is only the principal determinant of animal performance $[4,5,7]$. Therefore, grazing management that is optimized for forage dry matter intake (DMI) with a high nutritive value is desired. Based on this, a study was conducted using a range of sward heights to evaluate grazing intensity impacts when managing Marandu palisade grass.

Grazers affect the cycling of carbon $(\mathrm{C})$ and nitrogen $(\mathrm{N})$ within pastures via defoliation, excretal returns, and trampling. In pastures, animals emit carbon dioxide $\left(\mathrm{CO}_{2}\right)$ via their metabolic activity and $\mathrm{CH}_{4}$ through enteric fermentation [11]. Nitrous oxide $\left(\mathrm{N}_{2} \mathrm{O}\right)$ is also emitted when excreta and forage residues decompose. Greenhouse gases from the soil are affected by soil structure, particularly compaction, which affects soil moisture, oxygen $\left(\mathrm{O}_{2}\right)$ availability, and animal emissions $[3,12,13]$. Grazing Marandu to a $15 \mathrm{~cm}$ sward height implies a greater stocking rate, and hence more excretal returns and soil trampling by the animals. One of the assumptions investigated by this study was that $\mathrm{CH}_{4}$ and $\mathrm{N}_{2} \mathrm{O}$ emissions per area would decrease, while $\mathrm{CO}_{2}$ emissions per area would rise with increasing sward heights.

Enteric $\mathrm{CH}_{4}$ is produced in the rumen by methanogenic Archaea that use the hydrogen $\left(\mathrm{H}_{2}\right)$ produced during the feed fermentation process. Methanogenesis is essential for the optimal performance of the rumen because it avoids $\mathrm{H}_{2}$ accumulation [14]. The main feed components that affect fermentation by microbiota are the fiber components (cellulose and hemicellulose), which vary when the forage sward is managed at different heights. Therefore, sward height may affect enteric $\mathrm{CH}_{4}$ production. There have been few previous reports on GHG emissions from cattle grazing tropical pastures. For national GHG inventories in Latin America, the Intergovernmental Panel on Climate Change (IPCC) guide recognized an emission factor default of $56 \mathrm{~kg} \mathrm{CH}_{4}$ head $^{-1}$ year $^{-1}$ for adult beef cattle [15]. Therefore, it was hypothesized that daily $\mathrm{CH}_{4}$ methane emissions per animal would decrease with increasing sward heights and would differ from the IPCC emission factors.

The relationships among forage production, canopy structure, nutritive value, and animal performance are complex according to long-term studies. The grazing intensity may have the greatest effect because it is the most important component of grazing management. The aims of this study were (1) to analyze the effects of different sward heights on herbage mass, plant morphological structure, herbage nutritive value, soil and animal GHG emissions, and animal performance; (2) identify relationships among variables that explain the variation in forage nutritive value and animal performance; and (3) verify which variables best explain GHG production in the soil and how these emissions are affected by season. There were two main hypotheses underlying the study. The first was that maintaining a lower sward height $(15 \mathrm{~cm})$ would result in a greater herbage nutritive value and animal production per area, while a sward height of $25 \mathrm{~cm}$ will produce the best relationship between herbage mass, animal production per area, and animal characteristics. The second was that the fiber and lignin concentrations and the proportion of stem and dead material would increase 
with pasture height. The analysis used data from a 7 year experiment on a tropical grass; Marandu palisade grass.

\section{Materials and Methods}

\subsection{Experimental Site and Grazing Management}

The data originated from a series of experiments carried out from 1 December 2007 to 31 March 2014. The experimental site was located within the Forage and Grasslands sector at São Paulo State University, "Julio de Mesquita Filho" (UNESP) (Jaboticabal, São Paulo, Brazil). The climate in this region is classified as a humid subtropical type with wet summers and dry winters. The average annual rainfall is $1424 \mathrm{~mm}$, and the average air temperature is $22.3^{\circ} \mathrm{C}$. Rainfall and air temperature were measured during the experiment (Table 1). The soil is a Rhodic Ferralsol [16] derived from basalt, and the pasture was planted with Marandu palisade grass in 2001. The experimental area from 2008 to 2014 was divided into 18 experimental paddocks. Six paddocks per treatment with $0.7,1.0$ and 1.3 ha for 35,25 , and $15 \mathrm{~cm}$, respectively. The reserve area was 5.0 ha in size.

Table 1. Days (d) with rain, rainfall ( $\mathrm{mm}$ ), and average air temperatures during the experimental period.

\begin{tabular}{cccccc}
\hline Period & $\begin{array}{c}\text { Days with Rain } \\
(\mathbf{d})\end{array}$ & $\begin{array}{c}\text { Rainfall } \\
(\mathbf{m m})\end{array}$ & \multicolumn{3}{c}{ Temperature $\left({ }^{\circ} \mathbf{C}\right)$} \\
Max. & Min. & Mean \\
\hline December 2005/May 2006 & 82 & 1089 & 31.3 & 17.2 & 23.2 \\
December 2006/May 2007 & 95 & 1009 & 317 & 18.7 & 24.2 \\
December 2007/May 2008 & 86 & 1145 & 30.3 & 14.2 & 22.8 \\
December 2008/May 2009 & 87 & 1105 & 32.1 & 17.2 & 23.4 \\
October 2010/May 2011 & 92 & 1455 & 31.1 & 17.7 & 23.1 \\
January 2012/May 2012 & 47 & 454 & 31.8 & 18.2 & 25.0 \\
December 2012/May 2013 & 75 & 1047 & 29.8 & 18.4 & 23.1 \\
October 2013/April 2014 & 78 & 832 & 32.2 & 17.1 & 24.1 \\
\hline
\end{tabular}

The pasture was fertilized on a regular basis according to the recommendations from the Committee for Fertilization and Liming of São Paulo State after considering the soil chemical analyses and forage production targets [17]. In the studied area, fertilization occurred during the rainy season in the Months of November to March. The fertilizer application schedule is summarized in Table 2 based on soil chemical analyses conducted every year.

In the studied region, the forage growing season began in October and finished in April. During the dry period, the animals remained in the field and received silage and concentrates, or the stocking rates were reduced by the farms. In the period of May to September, $11 \%$ of the slaughtered animals were finished in the feedlots. In the present study, the pasture was continuously stocked with young bulls (Bos indicus var. Nellore), and Nellore crosses with other B. indicus. The animals arrived at the experimental area in October and November. In November, the pastures achieved the desired sward height. In general, the experiments commenced in December after $15 \mathrm{~d}$ of adaptation and were conducted for 84 or 112 days ( 3 or 4 periods of 28 day).

The bulls used in the experiments were 10-12 months old and weighed 180-230 kg when the evaluations began. They were identified, weighed, and randomly distributed in groups of six bulls "testers" per paddock (108 experimental animals). Some animals (40-45 put and take animals) were used to maintain the sward height using the put-and-take method [18]. In the put-and-take method, there are fixed animals "testers" and put and take animals used to adjust the stocking rate according to the herbage accumulation (mass production) to keep the management target (sward height in this study). The height/herbage mass relationship (bulk density) was used weekly to adjust the stocking rate by use of the put and take animals. 
Table 2. Description of pasture fertilization during the experimental period. N: nitrogen; P: phosphorus; $\mathrm{K}:$ potassium.

\begin{tabular}{|c|c|c|c|}
\hline Year & $\begin{array}{l}\text { Fertilization and Lime } \\
\text { Application }\end{array}$ & Top-Dressed Fertilization & Fertilization Schedule \\
\hline 2006 & & $\begin{array}{l}200 \mathrm{~kg} \mathrm{ha}^{-1} \mathrm{~N} \text { (urea and } 160 \mathrm{~kg} \\
\mathrm{ha}^{-1} \mathrm{~K}_{2} \mathrm{O} \text { (Potassium chloride) }\end{array}$ & $\begin{array}{l}\text { split over two } \\
\text { applications }\end{array}$ \\
\hline 2007 & 50,25 , and $50 \mathrm{~kg} \mathrm{ha}^{-1}$ of NPK & $50 \mathrm{~kg} \mathrm{ha}^{-1} \mathrm{~N}$ (urea) & one application \\
\hline 2008 & 50,25 , and $50 \mathrm{~kg} \mathrm{ha}^{-1}$ of NPK & $250 \mathrm{~kg} \mathrm{ha}^{-1} \mathrm{~N}$ (urea) & $\begin{array}{l}\text { split over three } \\
\text { applications }\end{array}$ \\
\hline 2009 & 12,42 , and $24 \mathrm{~kg} \mathrm{ha}^{-1}$ of NPK & $250 \mathrm{~kg} \mathrm{ha}^{-1} \mathrm{~N}$ (urea) & $\begin{array}{l}\text { split over two } \\
\text { applications }\end{array}$ \\
\hline 2011 & 8,28 , and $16 \mathrm{~kg} \mathrm{ha}^{-1}$ of NPK & $180 \mathrm{~kg} \mathrm{ha}^{-1} \mathrm{~N}$ (urea) & $\begin{array}{l}\text { split over four } \\
\text { applications }\end{array}$ \\
\hline 2012 & 25,25 , and $25 \mathrm{~kg} \mathrm{ha}^{-1}$ of NPK & $90 \mathrm{~kg} \mathrm{ha}^{-1} \mathrm{~N}$ (urea) & $\begin{array}{l}\text { split over two } \\
\text { applications }\end{array}$ \\
\hline 2013 & 7,20 , and $14 \mathrm{~kg} \mathrm{ha}^{-1}$ of NPK & $160 \mathrm{~kg} \mathrm{ha}^{-1} \mathrm{~N}$ (urea) & $\begin{array}{l}\text { split over three } \\
\text { applications }\end{array}$ \\
\hline 2014 & $\begin{array}{l}1000 \mathrm{~kg} \mathrm{ha}^{-1} \text { of dolomitic lime } \\
\text { and } 4 \text { and } 62 \mathrm{~kg} \mathrm{ha}^{-1} \text { of } \mathrm{N} \text { and } \mathrm{P}\end{array}$ & $\begin{array}{l}180 \text { and } 40 \mathrm{~kg} \mathrm{ha}^{-1} \text { of } \\
\text { formulated } \mathrm{N} \text { and } \mathrm{K}\end{array}$ & $\begin{array}{l}\text { split over four } \\
\text { applications }\end{array}$ \\
\hline
\end{tabular}

\subsection{Experiments and Treatments}

From 2008 to 2014, the treatments were three sward heights $(15,25$, and $35 \mathrm{~cm})$ in a completely randomized block with six replications per treatment. The factor of blocking was soil topography.

\subsection{Response Variables}

Herbage mass, sward canopy structure, herbage nutritive value, and animal performance were measured between 2008 and 2014; forage intake was quantified between 2007 and 2014; enteric $\mathrm{CH}_{4}$ was measured between 2012 and 2014; and soil GHG emissions and other explanatory variables were quantified in 2013 and 2014. The source of the data was the nine dissertations or theses listed in the Supplementary Information SI.

Grazing heights were measured weekly using a graduated rule at 80 random points ("hits") per paddock and the data were used to estimate average sward height. The forage mass was estimated by clipping eight $0.25 \mathrm{~m}^{2}$ quadrats at average paddock sward height locations in each pasture to a residual height of $5 \mathrm{~cm}$ every $28 \mathrm{~d}$ during the measurement period. The forage samples were separated into dead material, stem + leaf sheaths, and live leaves. Then they were dried at $55 \pm 5^{\circ} \mathrm{C}$ to constant weight to estimate dry matter (DM) ha ${ }^{-1}$. The forage nutritive value, was estimated by hand-plucking method, samples every $28 \mathrm{~d}$ ( 20 samples per plot). These were then dried at $55 \pm 5^{\circ} \mathrm{C}$ to a constant weight and ground through a 1-mm screen in a shear mill (Thomas-Wiley Laboratory Mill Model 4, H. Thomas Co, São Paulo, Brazil.) for subsequent analyses.

Forage $\mathrm{CP}, \mathrm{NDF}, \mathrm{ADF}$, Ether Extract, and lignin concentrations were determined using the standard procedures outlined by the AOAC (1990). Indigestible NDF was quantified by incubating hand-plucking and feces samples dried at $55 \pm 5^{\circ} \mathrm{C}$ to a constant weight and ground through a $2 \mathrm{~mm}$ for 244 in the rumen. The following equation was used to determine the apparent digestibility of DM: digestibility $(\%)=100-(100 \times($ iNDF in hand-plucking sample/iNDF in feces $) \times($ nutrient concentration in feces/nutrient concentration in feedstuff) Enteric $\mathrm{CH}_{4}$ was measured using a tracer gas method (sulfur hexafluoride- $\mathrm{SF}_{6}$ ) in 2012, 2013, and 2014. The complete methodologies are described in Barbero et al. (2015) [19].

Animal performance variables were calculated as follows [18]:

Body weight gain-BW gain $(\mathrm{kg})=($ final BW - initial BW $)$; 
Average daily gain $-\mathrm{ADG}\left(\mathrm{kg}\right.$ animal $\left.{ }^{-1} \mathrm{day}^{-1}\right)=(\mathrm{BW}$ gain $(\mathrm{kg}) / \mathrm{days})$;

Gain per area-GPH $=($ ADG $\times$ number of animals per days $\times$ experimental period (days) $) /$ area (ha), where the number of animal days (animal day ${ }^{-1} \mathrm{ha}^{-1}$ ) was calculated by dividing animal stock by the mean weight of "testers". Animal stock was determined by the sum of weights of all animals present in each paddock divided by the area of the paddock $\left(\mathrm{kg} \mathrm{BW} \mathrm{ha}^{-1}\right)$;

Stocking rate in animal unit $(\mathrm{AU}=450 \mathrm{~kg} \mathrm{BW}) / \mathrm{ha}=\left(\sum\right.$ BWmean/450)/area (ha);

Greenhouse gases from the soil were quantified using the static closed chamber method described by Cardoso et al. (2017) [12]. The explanatory variables for soil moisture, ammonium, and nitrate were quantified at the $0-20 \mathrm{~cm}$ soil depth. Soil samples of the $0-10 \mathrm{~cm}$ layer were sampled at each air collecting event to quantify mineral $\mathrm{N}$, gravimetric water content (by drying soil at $105^{\circ} \mathrm{C}$ ), and percent water filled pore space (WFPS). Soil bulk density in the $0-10 \mathrm{~cm}$ layer was determined using a cylinder $50 \mathrm{~mm}$ in diameter and $50 \mathrm{~mm}$ in height. WFPS was calculated from the gravimetric water content and bulk density using a particle density of $2.65 \mathrm{~g} \mathrm{~cm}^{-3}$. For mineral $\mathrm{N}$ analysis, extraction with $2 \mathrm{M} \mathrm{KCl}$ was done on field moist samples with correction for water content. Ammonium-N was determined using the Berthelot reaction with spectrometry at $647 \mathrm{~nm}$. Nitrate-N quantification was carried out by ultraviolet absorption spectrometry at 220 [12]. Air temperatures, moisture, precipitation, and solar radiation were obtained from a meteorological station located $500 \mathrm{~m}$ away from the study area.

\subsection{Statistical Analysis}

Data were analyzed as repeated measures using the LME procedure in R (package NLME, R Core Team, https://svn.r-project.org/R-packages/trunk/nlme/). The model included sward height, years, and sward height versus year interactions as fixed effects, and paddock or animal as the random effect. Non-structured covariance was used for the repeated-measures analyses because it had the lowest Akaike Information Criterion. Orthogonal polynomial contrasts were performed when a significant effect was found.

Principal component analysis (PCA) was obtained from a correlation matrix using the R package "FactoMineR" (http://factominer.free.fr/). The categories analyzed were: (1). Forage mass and structure (Dry matter mass, leaf mass, stem mass, dead material mass, $\%$ of leaf, $\%$ of stem, $\%$ of dead material, and leaf/stem ratio), and (2) Nutritive value (Organic Matter\%, $\mathrm{CP} \%, \mathrm{NDF} \%$, and lignin $\%$ of DM),

In this study, canonical correlation analysis (CCA) was used to correlate monthly observations of climate independent variables (air temperature, air moisture, rainfall and solar radiation) with dependent variables: herbage mass and structure (Dry matter mass, leaf mass, stem mass, dead material mass, $\%$ of leaf, $\%$ of stem, $\%$ of dead material, and leaf/stem ratio). And, for the GHG from soil analysis, the climate variables (mean, minimal, and maximal air temperature; mean, minimal, and maximal air moisture; rainfall; and solar radiation) were the independent variables and $\mathrm{CO}_{2}, \mathrm{~N}_{2} \mathrm{O}$, and $\mathrm{CH}_{4}$ fluxes were the dependent variables. Daily data were used. The best multiple regression model was chosen using $R^{2}$ and the significance of the model was calculated by the "FactoMinerR" package in $\mathrm{R}$ ( $\mathrm{R}$ Core Team, 2016).

\section{Results}

\subsection{Forage Mass and Structure}

Pasture height affected herbage mass $(p<0.0001)$, leaf mass $(p<0.0001)$, stem mass $(p<0.0001)$, dead material mass $(p<0.0001)$, \% of leaves in the herbage $(p<0.006)$, and \% of stems $(p<0.0158)$, but not the percentage of dead material $(p=0.29)$. Herbage mass varied from $3460 \mathrm{DM} \mathrm{ha}^{-1}$ in 2009 in the $15 \mathrm{~cm}$ treatment to $11,000 \mathrm{~kg} \mathrm{DM} \mathrm{ha}^{-1}$ in 2013 in the $35 \mathrm{~cm}$ treatment. During the seven years of evaluation, herbage mass averaged 5230, 7810, and $9860 \mathrm{~kg} \mathrm{DM} \mathrm{ha}^{-1}$ for the 15, 25, and $35 \mathrm{~cm}$ treatments, respectively. Herbage mass increased linearly with sward height.

The lowest leaf mass was recorded in $2012\left(1330 \mathrm{~kg} \mathrm{DM} \mathrm{ha}^{-1}\right)$ and the highest in 2013 (4240 $\mathrm{kg} \mathrm{DM} \mathrm{ha}^{-1}$ ) (Table 3). The leaf mass range was 1760, 2460, and $3010 \mathrm{~kg} \mathrm{DM} \mathrm{ha}^{-1}$ for the 15 , 
25 , and $35 \mathrm{~cm}$ sward heights, respectively. The average stem mass at $35 \mathrm{~cm}$ height $\left(3560 \mathrm{~kg} \mathrm{DM} \mathrm{ha}^{-1}\right)$ was more than double the stem mass recorded at $15 \mathrm{~cm}\left(1490 \mathrm{~kg} \mathrm{DM} \mathrm{ha}^{-1}\right)$ and was greater than at $25 \mathrm{~cm}\left(2410 \mathrm{~kg} \mathrm{DM} \mathrm{ha}^{-1}\right)$. The greatest mass of dead material was found in 2008 and the lowest in 2013. The dead material mass averaged 1940, 2830, and $3220 \mathrm{~kg} \mathrm{DM} \mathrm{ha}^{-1}$, respectively, for the 15 , 25 , and $35 \mathrm{~cm}$ sward heights (Table 3). Leaf, stem, and dead material mass increased linearly with sward height.

The forage morphological composition results showed that the average leaf proportion decreased linearly from $40 \%$ to $35.7 \%$ as sward height increased ( $p=0.006$ ); the proportion due to stems increased linearly ( $p=0.0158$ ) from $42.6 \%$ to $45.2 \%$; and the $\%$ of dead material decreased linearly, with averages of $37.2,35.5$, and $32.6 \%$ for the 15,25 , and $35 \mathrm{~cm}$ sward heights, respectively, (Table 3).

\subsection{Nutritive Value}

The nutritive value results showed that sward height affected the organic matter (OM), NDF, and ADF values $(p<0.01)$. The effect of grazing intensity on $\mathrm{CP}$ and digestibility had $p$-values of 0.06 and 0.0548 , respectively. Table 4 shows that OM was similar across all treatments (approximately 91\%). Crude protein varied greatly among years and decreased linearly with sward height when all the year data were analyzed together. The highest CP occurred in $2011(16.3 \%)$ in the $15 \mathrm{~cm}$ treatment, whereas the lowest CP content was $11.2 \%$, which occurred in 2014. The CP content averaged 14.7, 14.0, and $14.0 \%$ for the 15,25 , and $35 \mathrm{~cm}$ sward heights, respectively.

Both the NDF and ADF fractions increased linearly with sward height. The highest NDF concentration was measured in 2009 for all treatments and the lowest in 2011. The average NDF values during the 7 years of evaluation were $57.8,59.1$, and $59.6 \%$ for the 15,25 , and $35 \mathrm{~cm}$ treatments, respectively. The ADF value for the $35 \mathrm{~cm}$ treatment (32.0\%) was significantly higher than 15 and $25 \mathrm{~cm}$ sward heights, which both averaged 30.4\%. Lignin content averaged 3.7, 3.8, and $4.2 \%$ for the 15 , 25 , and $35 \mathrm{~cm}$ treatments, respectively (Table 4). The results of principal component analysis identified that temperature and rainfall explained more than $80 \%$ of the variation in Marandu palisadegrass chemical composition (temperature explained $45 \%$ and rainfall $41 \%$ ). The canonical correlation analysis between the weather variables and nutritive value showed that rainfall and temperature were the most correlated variables. The coefficients were 0.23 and 0.49 for rainfall and temperature, respectively. The variation in the NDF content was explained by the variation in the temperature. The coefficient were 0.94 between NDF and temperature.

\subsection{Animal Performance}

Sward height affected daily weight gain $(p=0.027)$, which increased linearly by $0.668,0.892$, and $0.902 \mathrm{~kg}$ Body weight (BW) day ${ }^{-1}$ on average for the 15, 25, and $25 \mathrm{~cm}$ treatments, respectively (Table 5). The highest individual gain exceeded $1 \mathrm{~kg} \mathrm{BW} \mathrm{day}^{-1}$ and was observed in 2013, while the lowest was recorded in 2008. The highest gain per area was recorded in 2011 and 2013 at the highest grazing intensity (15 cm sward height), and the lowest was observed in 2008 in the $35 \mathrm{~cm}$ treatment (196 kg BW ha $\left.{ }^{-1}\right)$. Gain per area averaged 649, 530, and $439 \mathrm{~kg} \mathrm{BW} \mathrm{ha}^{-1}$ and was affected by sward height $(p=0.004)$. This gain was recorded during the rainy season (from December to April). Stocking rate was significantly affected by sward height $(p<0.0001)$ and decreased linearly in response to pasture height. The stocking rate averaged $6.13,4.73$, and 4.09 animal units ha ${ }^{-1}$ (1 animal unit equals $450 \mathrm{~kg} \mathrm{BW}$ ) for the 15,25 , and $35 \mathrm{~cm}$ treatments, respectively. 
Table 3. Herbage mass and structural characteristics of Marandu grass managed at different sward heights ${ }^{1}$.

\begin{tabular}{|c|c|c|c|c|c|c|c|}
\hline \multirow[b]{2}{*}{ Variable } & \multirow[b]{2}{*}{ Year } & \multicolumn{3}{|c|}{ Sward Height $(\mathrm{cm})$} & \multirow[b]{2}{*}{ Sward } & \multirow{2}{*}{$\begin{array}{c}p \text {-Value } \\
\text { Year }\end{array}$} & \multirow[b]{2}{*}{$S^{*} \mathbf{Y}$} \\
\hline & & 15 & 25 & 35 & & & \\
\hline \multirow{7}{*}{$\begin{array}{l}\text { Herbage mass } \\
\left(\mathrm{t} \mathrm{DM} \mathrm{ha}^{-1}\right)\end{array}$} & 2008 & 7.22 & 8.86 & 10.03 & \multirow{7}{*}{$p<0.001$} & \multirow{7}{*}{$p<0.001$} & \multirow{7}{*}{$p=0.298$} \\
\hline & 2009 & 3.46 & 5.08 & 7.45 & & & \\
\hline & 2011 & 4.95 & 9.24 & 10.22 & & & \\
\hline & 2012 & 4.37 & 7.59 & 9.61 & & & \\
\hline & 2013 & 5.99 & 7.74 & 11.02 & & & \\
\hline & 2014 & 5.36 & 8.37 & 10.83 & & & \\
\hline & Mean & 5.23 & 7.81 & 9.86 & & & \\
\hline \multirow{7}{*}{$\begin{array}{l}\text { Leaf mass } \\
\left(\mathrm{t} \mathrm{DM} \mathrm{ha}^{-1}\right)\end{array}$} & 2008 & 1.64 & 1.79 & 2.26 & \multirow{7}{*}{$p<0.001$} & \multirow{7}{*}{$p<0.001$} & \multirow{7}{*}{$p=0.435$} \\
\hline & 2009 & 1.45 & 2.39 & 2.39 & & & \\
\hline & 2011 & 1.43 & 2.47 & 2.92 & & & \\
\hline & 2012 & 1.33 & 2.15 & 2.82 & & & \\
\hline & 2013 & 2.59 & 3.16 & 4.24 & & & \\
\hline & 2014 & 2.10 & 2.80 & 3.43 & & & \\
\hline & Mean & 1.76 & 2.46 & 3.01 & & & \\
\hline \multirow{7}{*}{$\begin{array}{l}\text { Stem mass } \\
\left(\mathrm{t} \mathrm{DM} \mathrm{ha}^{-1}\right)\end{array}$} & 2008 & 1.84 & 2.71 & 3.59 & \multirow{7}{*}{$p<0.001$} & \multirow{7}{*}{$p<0.001$} & \multirow{7}{*}{$p=0.467$} \\
\hline & 2009 & 1.10 & 1.70 & 2.80 & & & \\
\hline & 2011 & 1.44 & 3.46 & 3.65 & & & \\
\hline & 2012 & 1.24 & 2.30 & 2.95 & & & \\
\hline & 2013 & 2.37 & 3.33 & 5.26 & & & \\
\hline & 2014 & 1.49 & 2.41 & 3.60 & & & \\
\hline & Mean & 1.58 & 2.65 & 3.64 & & & \\
\hline \multirow{7}{*}{$\begin{array}{l}\text { Dead material mass } \\
\qquad\left(\mathrm{t} \mathrm{DM} \mathrm{ha}{ }^{-1}\right)\end{array}$} & 2008 & 3.74 & 4.36 & 4.18 & \multirow{7}{*}{$p<0.001$} & & \\
\hline & 2009 & 1.24 & 1.75 & 2.26 & & & \\
\hline & 2011 & 2.08 & 3.31 & 3.65 & & & \\
\hline & 2012 & 1.80 & 3.14 & 3.85 & & $p<0.001$ & $p=0.657$ \\
\hline & 2013 & 1.03 & 1.24 & 1.52 & & & \\
\hline & 2014 & 1.76 & 3.17 & 3.84 & & & \\
\hline & Mean & 1.94 & 2.83 & 3.22 & & & \\
\hline & 2008 & 47.0 & 40.1 & 38.8 & & & \\
\hline & 2009 & 49.8 & 41.5 & 44.5 & & & \\
\hline & 2011 & 30.4 & 28.3 & 29.5 & & & \\
\hline$\%$ leaf & 2012 & 30.4 & 30.3 & 30.7 & $p=0.006$ & $p<0.001$ & $p=0.499$ \\
\hline & 2013 & 43.4 & 40.9 & 38.5 & & & \\
\hline & 2014 & 39.0 & 34.1 & 32.4 & & & \\
\hline & Mean & 40.0 & 35.9 & 35.7 & & & \\
\hline & 2008 & 53.0 & 60.0 & 61.0 & & & \\
\hline & 2009 & 48.8 & 47.4 & 43.5 & & & \\
\hline & 2011 & 58.5 & 58.5 & 55.5 & & & \\
\hline$\%$ stem & 2012 & 28.3 & 30.3 & 30.7 & $p<0.016$ & $p<0.001$ & $p=0.626$ \\
\hline & 2013 & 39.5 & 43.1 & 47.8 & & & \\
\hline & 2014 & 27.7 & 28.5 & 32.5 & & & \\
\hline & Mean & 42.6 & 44.6 & 45.2 & & & \\
\hline & 2008 & 50.8 & 48.7 & 41.1 & & & \\
\hline & 2009 & 38.9 & 35.1 & 30.1 & & & \\
\hline & 2011 & 41.5 & 34.2 & 35.4 & & & \\
\hline$\%$ dead material & 2012 & 41.3 & 41.4 & 39.8 & $p<0.29$ & $p=0.081$ & $p=0.822$ \\
\hline & 2013 & 17.2 & 16.0 & 13.8 & & & \\
\hline & 2014 & 33.3 & 37.4 & 35.1 & & & \\
\hline & Mean & 37.2 & 35.5 & 32.6 & & & \\
\hline
\end{tabular}

${ }^{1}$ Means of four evaluations between December and March of each year $(n=24) . S=$ sward and $\mathrm{Y}=$ year. $\mathrm{S}^{*} \mathrm{Y}$ (sward height versus year interactions). 
Table 4. Nutritive values for Marandu grass (hand plugged sample) managed at different sward heights ${ }^{1}$.

\begin{tabular}{|c|c|c|c|c|c|c|c|}
\hline \multirow[b]{2}{*}{ Variable } & \multicolumn{6}{|c|}{ Sward Height $(\mathrm{cm})$} & \multirow[b]{2}{*}{$S^{*} \mathbf{Y}$} \\
\hline & Year & 15 & 25 & 35 & Sward & Year & \\
\hline \multirow{7}{*}{ Organic matter $\left(\mathrm{g} \mathrm{kg}^{-1} \mathrm{DM}\right)$} & 2008 & 90.0 & 90.6 & 90.8 & \multirow{7}{*}{$p=0.0014$} & \multirow{7}{*}{$p<0.001$} & \multirow{7}{*}{$p=0.839$} \\
\hline & 2009 & 90.1 & 90.8 & 90.7 & & & \\
\hline & 2011 & 91.4 & 90.7 & 90.9 & & & \\
\hline & 2012 & 91.5 & 91.6 & 91.7 & & & \\
\hline & 2013 & 91.0 & 92.5 & 92.4 & & & \\
\hline & 2014 & 91.3 & 91.3 & 91.4 & & & \\
\hline & Mean & 90.9 & 91.3 & 91.3 & & & \\
\hline \multirow{7}{*}{ Crude protein $\left(\mathrm{g} \mathrm{kg}^{-1} \mathrm{DM}\right)$} & 2008 & 15.8 & 15.6 & 14.6 & \multirow{7}{*}{$p=0.06$} & \multirow{7}{*}{$p<0.001$} & \multirow{7}{*}{$p=0.093$} \\
\hline & 2009 & 14.7 & 14.5 & 13.6 & & & \\
\hline & 2011 & 16.3 & 15.3 & 14.7 & & & \\
\hline & 2012 & 13.5 & 13.4 & 12.6 & & & \\
\hline & 2013 & 15.1 & 13.9 & 13.7 & & & \\
\hline & 2014 & 12.7 & 11.2 & 14.7 & & & \\
\hline & Mean & 14.7 & 14.0 & 14.0 & & & \\
\hline \multirow{7}{*}{$\begin{array}{l}\text { Neutral detergent fiber } \\
\qquad\left(\mathrm{g} \mathrm{kg}^{-1} \mathrm{DM}\right)\end{array}$} & 2008 & 57.2 & 60.4 & 59.9 & \multirow{7}{*}{$p=0.0043$} & \multirow{7}{*}{$p<0.001$} & \multirow{7}{*}{$p=0.753$} \\
\hline & 2009 & 60.6 & 61.1 & 63.0 & & & \\
\hline & 2011 & 54.7 & 54.6 & 55.6 & & & \\
\hline & 2012 & 57.6 & 57.5 & 58.9 & & & \\
\hline & 2013 & 57.7 & 60.0 & 59.9 & & & \\
\hline & 2014 & 59.1 & 61.2 & 60.0 & & & \\
\hline & Mean & 57.8 & 59.1 & 59.6 & & & \\
\hline \multirow{7}{*}{$\begin{array}{l}\text { Acid detergent fiber } \\
\qquad\left(\mathrm{g} \mathrm{kg}^{-1} \mathrm{DM}\right)\end{array}$} & 2008 & 33.7 & 34.1 & 39.9 & \multirow{7}{*}{$p=0.033$} & \multirow{7}{*}{$p=0.099$} & \multirow{7}{*}{$p=0.006$} \\
\hline & 2009 & 28.7 & 28.8 & 30.1 & & & \\
\hline & 2011 & 28.5 & 28.4 & 35.6 & & & \\
\hline & 2012 & 26.0 & 26.0 & 26.2 & & & \\
\hline & 2013 & 28.9 & 29.3 & 29.7 & & & \\
\hline & 2014 & 34.4 & 34.0 & 34.1 & & & \\
\hline & Mean & 30.4 & 30.4 & 32.0 & & & \\
\hline \multirow{7}{*}{$\operatorname{Lignin}\left(\mathrm{g} \mathrm{kg}^{-1} \mathrm{DM}\right)$} & 2008 & 4.6 & 3.9 & 5.7 & \multirow{7}{*}{$p=0.78$} & \multirow{7}{*}{$p<0.01$} & \multirow{7}{*}{$p=0.31$} \\
\hline & 2009 & 4.6 & 4.7 & 5.0 & & & \\
\hline & 2011 & 2.8 & 3.5 & 3.6 & & & \\
\hline & 2012 & 3.3 & 3.3 & 3.2 & & & \\
\hline & 2013 & - & - & - & & & \\
\hline & 2014 & 3.2 & 3.4 & 3.7 & & & \\
\hline & Mean & 3.7 & 3.8 & 4.2 & & & \\
\hline & 2008 & 75.8 & 78.7 & 77.0 & & & \\
\hline & 2009 & 57.3 & 54.7 & 60.2 & & & \\
\hline & 2011 & 59.5 & 56.0 & 68.6 & & & \\
\hline Digestibility of dry matter & 2012 & 63.8 & 64.0 & 69.0 & $p=0.055$ & $p<0.001$ & $p=0.805$ \\
\hline & 2013 & 72.8 & 70.4 & 68.5 & & & \\
\hline & 2014 & 71.3 & 70.5 & 66.6 & & & \\
\hline & Mean & 65.4 & 64.6 & 68.2 & & & \\
\hline
\end{tabular}

${ }^{1}$. Means of four evaluations between December and March of each year. $(n=24)$. $S=$ sward and $\mathrm{Y}=$ year. $\mathrm{S}^{*} \mathrm{Y}=$ sward height and year interaction. 
Table 5. Animal performance (gain per animal and area) in Marandu grass pastures managed at different sward heights ${ }^{1}$.

\begin{tabular}{|c|c|c|c|c|c|c|c|}
\hline \multicolumn{8}{|c|}{ Treatment (cm) } \\
\hline Variable & Year & 15 & 25 & 35 & Sward & Year & $S^{*} \mathbf{Y}$ \\
\hline \multirow{7}{*}{ Average daily gain $\left(\mathrm{kg}\right.$ day $\left.^{-1}\right)$} & 2008 & 0.32 & 0.63 & 0.76 & \multirow{7}{*}{$p=0.027$} & \multirow{7}{*}{$p<0.001$} & \multirow{7}{*}{$p=0.644$} \\
\hline & 2009 & 0.61 & 0.73 & 0.78 & & & \\
\hline & 2011 & 0.69 & 0.87 & 0.95 & & & \\
\hline & 2012 & 0.40 & 0.60 & 0.80 & & & \\
\hline & 2013 & 1.08 & 1.15 & 1.20 & & & \\
\hline & 2014 & 0.91 & 0.89 & 0.91 & & & \\
\hline & Mean & 0.67 & 0.81 & 0.90 & & & \\
\hline \multirow{7}{*}{ Gain per area $\left(\mathrm{kg} \mathrm{ha}^{-1}\right)$} & 2008 & 506 & 278 & 196 & \multirow{7}{*}{$p<0.001$} & \multirow{7}{*}{$p=0.544$} & \multirow{7}{*}{$p=0.739$} \\
\hline & 2009 & 744 & 672 & 576 & & & \\
\hline & 2011 & 778 & 715 & 602 & & & \\
\hline & 2012 & 492 & 528 & 468 & & & \\
\hline & 2013 & 778 & 578 & 470 & & & \\
\hline & 2014 & 597 & 410 & 322 & & & \\
\hline & Mean & 649 & 530 & 439 & & & \\
\hline \multirow{7}{*}{$\begin{array}{l}\left.\text { Stocking rate (AU ha }{ }^{-1}\right) \\
{ }^{1} \text { Animal unit (AU) equals } \\
450 \mathrm{~kg} \text { of body weight }\end{array}$} & 2008 & 5.49 & 3.92 & 4.63 & \multirow{7}{*}{$p<0.001$} & \multirow{7}{*}{$p<0.001$} & \multirow{7}{*}{$p=0.476$} \\
\hline & 2009 & 5.01 & 4.96 & 5.86 & & & \\
\hline & 2011 & 5.33 & 4.32 & 3.20 & & & \\
\hline & 2012 & 6.64 & 4.51 & 3.42 & & & \\
\hline & 2013 & 8.20 & 5.81 & 4.42 & & & \\
\hline & 2014 & 7.01 & 4.93 & 3.80 & & & \\
\hline & Mean & 6.13 & 4.73 & 4.09 & & & \\
\hline
\end{tabular}

${ }^{1}$ Four evaluations between December and March of each year. $(n=142) . S=$ sward and $\mathrm{Y}=$ year. $\mathrm{S}^{*} \mathrm{Y}=$ sward height and year interaction.

\subsection{Enteric Methane}

Daily $\mathrm{CH}_{4}$ emissions per animal were affected by sward height $(p=0.002)$ and year $(p<0.0001)$, but there was no interaction sward height and year. They increased linearly and per kg of BW gain $(p=0.012)$ e varied within year $(p=0.0003)$. In 2013, $\mathrm{CH}_{4}$ emissions decreased with increasing average daily gain, whereas, an inverse effect was observed in 2014. A summary of the enteric $\mathrm{CH}_{4}$ data is shown in Table 6. Enteric $\mathrm{CH}_{4}$ averaged 117, 126, and $139 \mathrm{~g}$ animal $^{-1}$ day $^{-1}$ for the 15, 25, and $35 \mathrm{~cm}$ treatments, respectively, and the emissions per gain ( $\mathrm{g} \mathrm{kg}^{-1} \mathrm{BW}$ gain) followed a similar pattern to the daily emissions.

\subsection{Greenhouse Gases}

Soil GHGs were measured from 2012 to 2014 in the long-term study and the results showed that grazing intensity affected GHG emissions. Nitrous oxide decreased, $\mathrm{CO}_{2}$ increased, and $\mathrm{CH}_{4}$ showed a curvilinear response to increased sward height. Only the highest grazing intensity $(15 \mathrm{~cm}$ sward height) produced net $\mathrm{N}_{2} \mathrm{O}$ emissions. Furthermore, $\mathrm{N}_{2} \mathrm{O}$ consumption increased with sward height (Table 7). The lowest $\mathrm{CH}_{4}$ emissions were recorded in the $25 \mathrm{~cm}$ treatment, and the results showed that sward height caused a $\mathrm{CO}_{2}$ emissions increase from 44.2 to $80 \mathrm{Mg} \mathrm{CO}_{2} \mathrm{ha}^{-1}$, which was the largest sward height effect within the analyzed gases $\left(r^{2}=0.95\right)$. 
Table 6. Enteric $\mathrm{CH}_{4}$ emissions from Nellore bulls fed on Marandu grass managed at different sward heights ${ }^{1}$.

\begin{tabular}{|c|c|c|c|c|c|c|c|}
\hline \multirow[b]{2}{*}{ Variable } & \multicolumn{6}{|c|}{ Sward Height $(\mathrm{cm})$} & \multirow[b]{2}{*}{$S^{*} \mathbf{Y}$} \\
\hline & Year & 15 & 25 & 35 & Sward & Year & \\
\hline \multirow{4}{*}{$\begin{array}{c}\text { Daily } \mathrm{CH}_{4} \text { emissions } \\
\left(\mathrm{g}_{\text {animal }}{ }^{-1} \text { day }^{-1}\right)\end{array}$} & 2012 & 107 & 179 & 184 & \multirow{4}{*}{$p=0.002$} & \multirow{4}{*}{$p<0.0001$} & \multirow{4}{*}{$p=0.193$} \\
\hline & 2013 & 129 & 132 & 123 & & & \\
\hline & 2014 & 106 & 119 & 155 & & & \\
\hline & Mean & 114 & 141 & 156 & & & \\
\hline \multirow{4}{*}{$\begin{array}{l}\text { Emissions per gain } \\
\left(\mathrm{g} \mathrm{kg}^{-1} \mathrm{BW} \text { gain }\right)\end{array}$} & 2012 & 117 & 191 & 174 & \multirow{4}{*}{$p=0.012$} & \multirow{4}{*}{$p=0.0003$} & \multirow{4}{*}{$p=0.459$} \\
\hline & 2013 & 119 & 115 & 101 & & & \\
\hline & 2014 & 115 & 136 & 177 & & & \\
\hline & Mean & 114 & 149 & 154 & & & \\
\hline
\end{tabular}

${ }^{1}$ One evaluation per year. $(n=18)$. BW-body weight, S-sward height and $\mathrm{Y}$-year. $\mathrm{S}^{*} \mathrm{Y}=$ sward height and year interaction.

Table 7. Cumulative $\mathrm{N}_{2} \mathrm{O}\left(\mathrm{kg} \mathrm{N}_{2} \mathrm{O}-\mathrm{N} \mathrm{ha}{ }^{-1}\right), \mathrm{CH}_{4}\left(\mathrm{~kg} \mathrm{CH}_{4}-\mathrm{C}\right.$ ha $\left.{ }^{-1}\right)$, and $\mathrm{CO}_{2}\left(\mathrm{Mg} \mathrm{CO}_{2} \mathrm{ha}^{-1}\right)$ emissions for Marandu grass managed at different sward heights ${ }^{1}$.

\begin{tabular}{cccccc}
\hline \multicolumn{3}{c}{ Sward Height $(\mathbf{c m})^{2}$} & & $p$-Value & \\
\hline & 15 & 25 & 35 & & Effect \\
$\mathrm{N}_{2} \mathrm{O}$ & $0.73(0.69)^{2}$ & $-1.11(1.10)$ & $-2.64(1.05)$ & $p<0.01$ & Linear \\
$\mathrm{CH}_{4}$ & $0.21(0.06)$ & $0.11(0.05)$ & $0.85(0.50)$ & $p<0.01$ & ns \\
$\mathrm{CO}_{2}$ & $44.2(3.1)$ & $59.4(3.9)$ & $80.0(6)$ & $p<0.01$ & Linear \\
\hline \multicolumn{4}{l}{${ }^{1}$ 2 years of evaluation $(n=6) .{ }^{2}$ Within parentheses: standard error of the mean $( \pm)}$.
\end{tabular}

The principal components analysis for GHGs emissions and explanatory variables identified that there was a clear positive correlation between soil moisture, and $\mathrm{CO}_{2}$ and $\mathrm{N}_{2} \mathrm{O}$ emissions. Soil ammonium and nitrate were also correlated with these gases. However, soil $\mathrm{CH}_{4}$ was not correlated with the variables (Figure 1). The CCA was performed to identify linear correlations between the grouping identified in the PCA analysis. The CCA showed the correlation between $\mathrm{N}_{2} \mathrm{O}$ and $\mathrm{CO}_{2}$ of 0.38 and with moisture of 0.48 . The correlation with ammonium and nitrate was negative -0.53 and -0.49 , respectively.

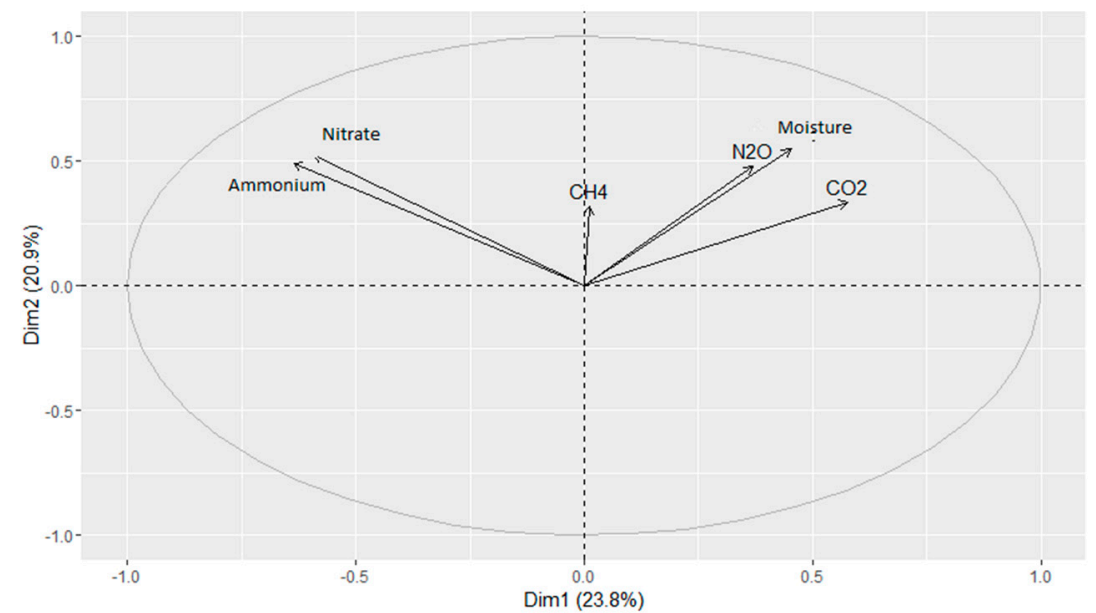

Figure 1. Principal Correlation Analysis between greenhouse gases and the explanatory variables for Marandu grass pastureland managed at different sward heights during the period 2012-2014. Dim1 (principal component 1) and Dim2 (principal component 1). 


\section{Discussion}

\subsection{Sward Structure}

This study aimed to show how sward structure affects forage quality. Despite the difference in herbage mass over the years, the \% proportions of leaves and stems had consistent relationships with sward height (Figure 2). The sward structure variables are conditioned by sward height and environmental variables (temperature, nitrogen fertilization, and light) [2,19-22]. The highest percentage proportion due to stems was recorded in the $35 \mathrm{~cm}$ treatment and was the result of stem elongation (Table 2).

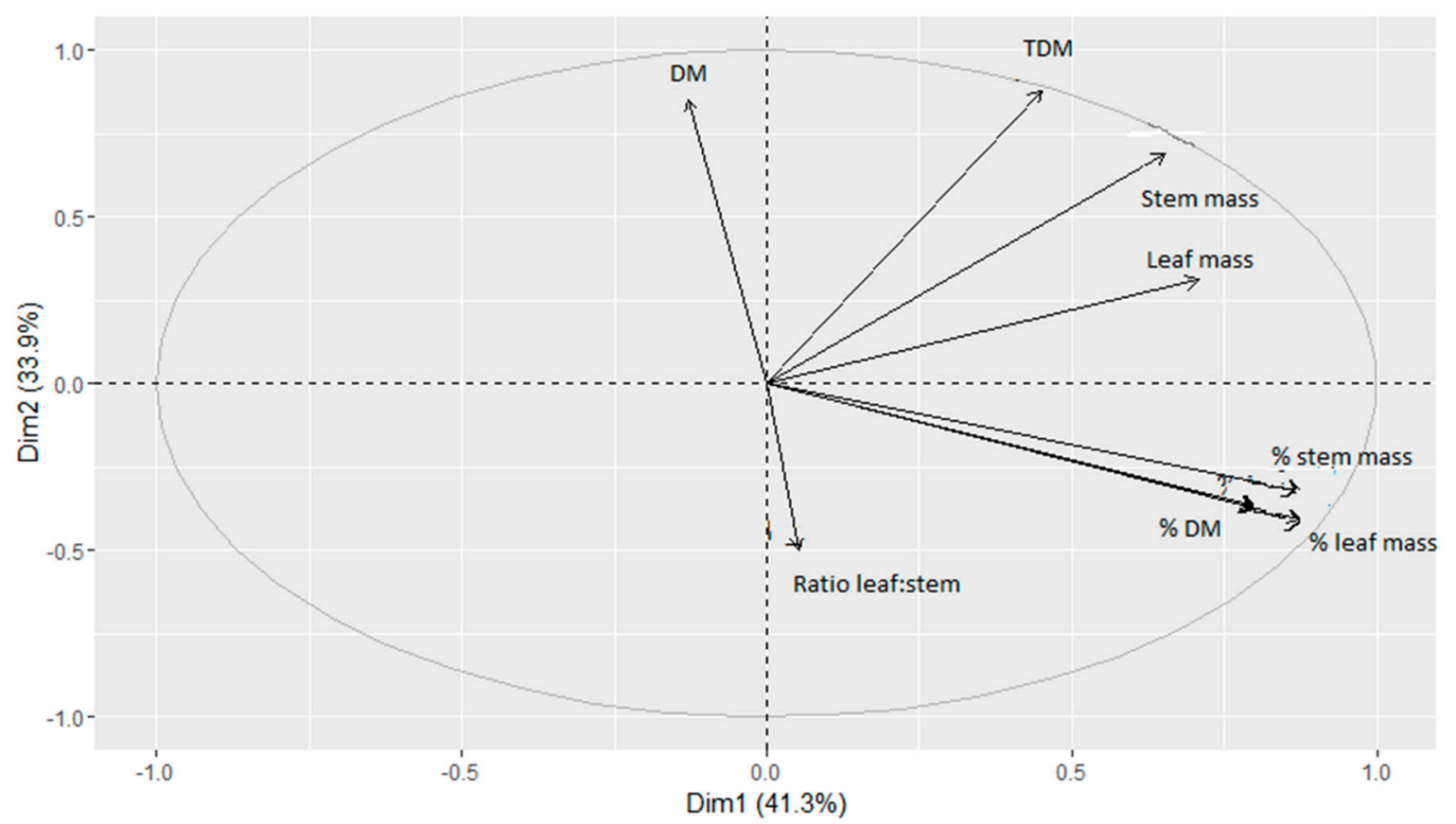

Figure 2. Principal component analysis between forage mass and the sward structure variables between 2008 and 2014. Dim 1 (principal component 1), Dim2 (principal component 2), TDM-herbage mass, DM-dead material, dead material \% (\% DM).

A minimal herbage mass of $2000 \mathrm{~kg} \mathrm{DM} \mathrm{ha}^{-1}$ is required for animal selection and is the recommended amount to sustain animal gains [7]. The results from this study showed that the herbage mass varied from 5230 to $11,120 \mathrm{~kg} \mathrm{DM} \mathrm{ha}^{-1}$, which resulted in bulk densities of 34.8, 31.2, and $28.1 \mathrm{~g} \mathrm{DM} \mathrm{m}^{-3}$ for the 15,25 , and $35 \mathrm{~cm}$ sward height treatments. A previous study found no differences in herbage mass among the sward heights, which averaged $4000 \mathrm{~kg} \mathrm{DM} \mathrm{ha}{ }^{-1}$ [19-23]. However, variations in soil fertility, rainfall, temperature, and solar radiation may explain the lower results recorded in this study compared to the previous study [23]. According to several studies, the potential production value for Marandu grass is about $11,000 \mathrm{~kg} \mathrm{DM} \mathrm{ha}^{-1} \mathrm{year}^{-1}$, which was also observed in 2013 by this study (Table 2) [14]. During the 2013 growing season, the measured herbage accumulation was $58 \mathrm{~kg} \mathrm{DM} \mathrm{day}{ }^{-1}$ [19]. Therefore, based on 6 months growing season, approximately $10,000 \mathrm{~kg}$ of $\mathrm{DM} \mathrm{ha}^{-1}$ is produced based on this herbage accumulation rate.

Grazing management aims to improve sward structure (physical characteristics, tissue distribution, anatomy, and leaf mass) and is an effective strategy that can be used to improve forage quality because changes in the structure variables can promote large differences in voluntary intake, which is the main factor that determines animal performance [24,25]. 


\subsection{Nutritive Value}

The observed mean CP and NDF contents found in this study varied from $14.0 \%$ to $14.7 \%$ and from $57.8 \%$ to $59.6 \%$, respectively (Table 3 ). These values differed from several previous studies that used Marandu grass [10,26,27], but were in line with a study from Vietnam [28]. In the Brazilian studies, $\mathrm{CP}$ varied from $10 \%$ to $12 \%$ during the rainy season (November to April), and from $6 \%$ to $8 \%$ during the dry season, whereas NDF was always above $60 \%$.

The NDF content increased with stem proportion in the sward and as the forage matured, both of which are dependent on the environment $[2,19,20]$. A Pearson's correlation between NDF content and stem proportion generated a coefficient of 0.85 . The increase in NDF with sward height observed in this study was probably due to variations in grass structure. Changes in plant structure alter the sward interception of photosynthetically active radiation (PAR) when the nitrogen fertilization rate is the same among treatments. The critical leaf area index concept states that when the grass sward intercepts $95 \%$ of PAR, it approaches its maximum growth rate without the plant shading itself [29]. Intercepts higher than $95 \%$ of PAR increase senescence and the stem growth rate, but decrease the grass nutritive value (decrease in CP and increase in fiber content) and leaf production [29].

The discriminatory power of variables within each principal component is measured by multiple correlations [30]. The results of principal component analysis identified that temperature and rainfall explained more than $80 \%$ of the variation in Marandu grass chemical composition (temperature explained $45 \%$ and rainfall $41 \%$ ), which is in line with the findings for temperate grasses [31,32]. The simultaneous occurrence of high temperatures and drought can limit forage growth and change tissue chemical composition [32,33]. When analyzed separately, drought and temperature have been shown to alter the chemical composition of forage [33]. Elevated temperature and drought (inadequate soil moisture) change plant chemical composition by altering the concentrations of non-fibrous and fiber carbohydrates [34].

\subsection{Animal Performance}

In Brazil, Nellore calves are weaned at 7 months, and have an average BW of $210 \mathrm{~kg}$ [35]. This study used animals that were bought after weaning with initial body weights ranging from 180 to $230 \mathrm{~kg}$. The effect of initial body weight on average daily gain (ADG) was attributed to the differences in the genetic group, nutrition during pregnancy, and the cow-calf phase.

Cow nutrition during pregnancy can affect the development of the progeny. Previous studies have shown that progeny from cows fed on improved pastures have higher ADGs in the finishing phase, thicker fat layers, and greater meat tenderness [36]. The development of calves from cows that were well nourished has been compared with those subjected to nutritional restrictions. The results showed that deficient nutrition can reduce the birth weight by up to 35\% [37]. Furthermore, animals with lower birth weights have limited compensatory growth capabilities. In addition, when animals were slaughtered at the same age (30 months), the group with a higher birth weight showed significantly improved performances for carcass and meat cuts.

Dry matter intake (DMI) is the main variable regulating animal performance [38,39]. The DMI is controlled by numerous factors that interact with each other, such as animal characteristics, the environment, forage allowance, nutritive value, and management [40]. In this study, animal performance varied among years and sward heights.

Higher or lower ADGs and gain per hectare (GPH) values were not observed in the years with higher or lower accumulated precipitation, or the year where the grass had the highest $\mathrm{CP}$ (Table 1 , Table 3, and Table 5), which suggests that factors inherent to animals, such as body weight, genetic factors, and feed conversion, are mainly responsible for annual variations.

Overall ADG increased with pasture height. It has been shown that grazing selectivity changes with grazing intensity [41]. In taller swards, animals can select more leaves that have higher nutritive value, which leads to a greater ADG. Over the years, pastures with taller sward heights had greater live leaf mass per hectare and total mass per hectare values. Herbage live leaf content is a key predictor of 
beef cattle production because live leaves have the greatest nutritive value [10,42]. Herbage mass in this study was always greater than $5000 \mathrm{~kg} \mathrm{DM}^{-1} \mathrm{ha}^{-1}$, which meant that it was consistently higher than the $2000 \mathrm{~kg}$ recommended level, below which there is a limit to forage intake in Brachiaria pastures [7].

High intakes and animal performances are achieved when high herbage masses and allowances are provided and forage nutritive value is high. Sward height affects the number of meals per animal per day when it is less than $15 \mathrm{~cm}$, while the time per meal decreased with an increase in sward height [37]. Previous studies have also shown that a larger forage allowance increases the number of meals and reduces the time per meal $[20,43,44]$. The improved animal performance observed in this long-term study (Table 3) suggested that both nutritional and non-nutritional factors limited forage intake [39].

This study evaluated the performance of Nellore bulls in the rearing phase during the Marandu grass growing season (December to April). They received additional mineral salts and an average supplement of $150 \mathrm{~kg} \mathrm{~N}$. In Central Brazil, the ADG value without supplements is only $0.3 \mathrm{~kg}$ animal $^{-1}$ day $^{-1}$ [45], which is much lower than the results recorded in this study (approximately $0.8 \mathrm{~kg}$ animal $^{-1} \mathrm{day}^{-1}$ ) (Table 3). Therefore, animal performance can be increased in tropical regions by controlling sward height. The results obtained over the $7 \mathrm{yrs}$ of evaluation can be attributed to (1) greater forage mass ( $>2$ times greater than that found to limit intake), (2) a higher proportion of live leaves in the herbage mass $(>50 \%)$, (3) a grazing efficiency of $50 \%$ obtained using the put-and-take method, (4) high digestibility $(>60 \%)$, (5) a high CP level for tropical grasses $\left(>140 \mathrm{~g} \mathrm{~kg}^{-1}\right),(6)$ an NDF concentration of less than $60 \%$, and (7) an adequate protein/energy ratio (>150 g CP kg-1 DOM).

Improved grassland management regimes, where the aim is sustainable intensification, need to be based on an understanding of the seasonal variations in productivity, stocking rate, sward structure, soil fertility, and animal behavior. The focus should not only be on carcass production per animal or area. Furthermore, livestock intensification needs to reduce the environmental footprint produced by cattle farming and generate ecosystem services, such as improved soil quality, reduced erosion, and GHG emissions.

\subsection{Greenhouse Gases}

Enteric $\mathrm{CH}_{4}$ is affected by the chemical composition of forage. The $\mathrm{CH}_{4}$ amount produced by animals fed on forages rich in structural carbohydrates is greater than the amount produced by those fed diets with higher levels of non-structural carbohydrates [11,46,47]. The data from this study showed that in the first and third years, the results were in line with previous studies because they showed that NDF content and enteric $\mathrm{CH}_{4}$ production were greater in the $35 \mathrm{~cm}$ pasture treatment than in the other treatments (Table 6). However, the results also showed a higher variation in the treatment responses over the evaluation years. Other variables, such as animal genetics, may explain the differences between years.

The variation in $\mathrm{CH}_{4}$ emissions from 106 to $177 \mathrm{~g} \mathrm{CH}_{4}$ animal ${ }^{-1}$ day ${ }^{-1}$ among sward heights and years can be explained by dry matter intake variation (Table 6). Similar behavior was reported in previous studies where a large variation was found between daily $\mathrm{CH}_{4}$ emissions. This variation was attributed to forage selection by the animals and, consequently, to variations in daily dry matter intake [48,49]. In the $25 \mathrm{~cm}$ height treatment, the NDF concentration was lower, and digestibility and the leaf appearance rate were higher, which may explain the lower enteric $\mathrm{CH}_{4}$ production (Table 7). Harvesting forage at an earlier grass maturity stage has often been proposed as a strategy to decrease enteric $\mathrm{CH}_{4}$ production [50].

The IPCC guidelines for national inventories default emission factor for enteric $\mathrm{CH}_{4}$ from beef cattle with the same range of body weights studied here are $149 \mathrm{~g} \mathrm{CH}_{4}$ animal ${ }^{-1}$ day $^{-1}$ [51]. In this study, daily $\mathrm{CH}_{4}$ emissions ranged from 117 to $139 \mathrm{~g}$ animal $^{-1}$ day $^{-1}$ (Table 6). The enteric $\mathrm{CH}_{4}$ measured in this study was lower than the average IPCC emissions factor for tropical pasture $\left(149 \mathrm{~g}_{\text {animal }}{ }^{-1} \mathrm{day}^{-1}\right)$ but within the range of variability around the mean given in the IPCC guide. The results produced by this study appear to be the first reports of enteric $\mathrm{CH}_{4}$ emissions for cattle that have only consumed 
Brachiaria grass. The amount of $\mathrm{CH}_{4}$ emitted by tropical production systems requires measurements from long-term experiments across a specified region.

Grazing intensity effects $\mathrm{CO}_{2}$ and $\mathrm{N}_{2} \mathrm{O}$ emissions [12]. Both GHG emissions declined in this study as the grazing intensity decreased. However, these effects varied according to the season, and there was no overall effect due to grazing intensity. The correlation between soil variables and GHG emissions was analyzed, and the results showed that there was a positive correlation between soil moisture and $\mathrm{CO}_{2}$ and $\mathrm{N}_{2} \mathrm{O}$, whereas soil ammonium and nitrate were not correlated with GHG emissions (Figure 1).

Soil moisture supports biological activity $[52,53]$ and can control $\mathrm{CO}_{2}$ and $\mathrm{N}_{2} \mathrm{O}$ emissions. This control is probably due to changes in root biomass, microbial decomposition, and variations in substrate supply depending on soil moisture [54]. Indeed, GHG emissions in tropical grasslands are extremely affected by seasonal variations in the rainfall regime $[13,53,55]$. Soil moisture also controls $\mathrm{O}_{2}$ diffusivity and, consequently, aerobic conditions.

Nitrous oxide is produced during nitrification and denitrification reactions in the soil [56]. The results produced by this study were in line with several previous studies that reported a positive correlation between soil moisture and $\mathrm{N}_{2} \mathrm{O}[13,57,58]$. These studies attributed this effect to variations in $\mathrm{N}$ uptake by plants and microorganism populations, $\mathrm{N}$ transformations (mineralization, nitrification) in the soil, and, principally, increases in denitrification activity induced by reduced $\mathrm{O}_{2}$ diffusion into the soil.

The results showed that soil $\mathrm{NH}_{4}{ }^{+}$and $\mathrm{NO}_{3}{ }^{+}$were not correlated with $\mathrm{N}_{2} \mathrm{O}$ and $\mathrm{CO}_{2}$ emissions (Figure 1). However, mineral nitrogen concentration $\left(\mathrm{NH}_{4}{ }^{+}\right.$and $\left.\mathrm{NO}_{3}{ }^{-}\right)$has a controlling effect over $\mathrm{N}_{2} \mathrm{O}$ emissions from soils [59]. The reasons for the absence of a correlation between $\mathrm{N}_{2} \mathrm{O}$ production and mineral $\mathrm{N}$ in this study are not clear, but presumably, $\mathrm{N}$ was not a limiting factor during the experimental period, which suggests that it was soil moisture that drove the fluxes.

Methane fluxes from soil are driven by initial $\mathrm{C}$ and $\mathrm{N}$ concentrations, soil moisture, temperature, dissolved $\mathrm{N}$ and $\mathrm{C}$, and mineral $\mathrm{N}$ concentration $[53,60]$. The results did not show a clear correlation between $\mathrm{CH}_{4}$ fluxes and any soil variable (Figure 1). The $\mathrm{CH}_{4}$ emissions were probably driven by different variables depending on the season and forage management activities. It has been reported that Brachiaria pastures are not a source of $\mathrm{CH}_{4}$. These previous studies suggested that the well-drained conditions of this soil favored $\mathrm{CH}_{4}$ oxidation, which consequently offset the $\mathrm{CH}_{4}$ production [12].

\subsection{Practical Implications for Pasture Management}

From a production perspective, the results were consistent with the hypothesis that increasing sward height leads to a diminution in the sward leaf and crude protein content. However, due to the higher forage allowance, there is a greater possibility of animal diet selection, resulting in higher individual performance. The feed value of Marandu grass and animal performance was relatively high in the current study.

The results also showed that the lowest sward height produced the highest $\mathrm{N}_{2} \mathrm{O}$ emissions, which is the most potent GHG. Irrespective of pasture height, enteric $\mathrm{CH}_{4}$ production was lower than the IPCC emissions factor for beef cattle in Latin America by approximately 30\%. However, this is still within the range considered by the IPCC. The $\mathrm{CH}_{4}$ conversion factor $(\mathrm{Ym})$ factor, which represents the annual gross energy intake lost as $\mathrm{CH}_{4}$, was similar to that observed in high-quality forage for all sward heights. According to this IPCC guideline, high-quality forage has a Ym lower than 6\% [15]. In this study, the reported Ym was approximately 5\% [19].

The results showed that individual animal performance increased from 668 to $901 \mathrm{~g} \mathrm{day}^{-1}$, and gain per area decreased from 649 to $439 \mathrm{~kg} \mathrm{ha}^{-1}$ during the rearing phase. The GHG emissions during the rearing phase were calculated based on the data for enteric $\mathrm{CH}_{4}$ reported here and GHG emissions for soil reported by Cardoso et al. (2017) [12]. The GHG data were converted into equivalent carbon dioxide $\left(\mathrm{CO}_{2} \mathrm{eq}\right)$ using a global warming potential of 28 for $\mathrm{CH}_{4}$ and 265 for $\mathrm{N}_{2} \mathrm{O}$. The analysis showed that the carbon footprint was 3.28, 3.54, and $4.08 \mathrm{~kg} \mathrm{CO}_{2} \mathrm{eq} \mathrm{kg}^{-1} \mathrm{BW}$ gain during the rearing phase for each sward treatment. A sward height of $25 \mathrm{~cm}$ for Marandu grass clearly produced the best 
forage quality and environmental performance according to the individual and per unit area gain in live weight results. However, there are some important aspects to consider before this management strategy is recommended. For example, both the soil type and water availability in this study were suitable for grazing. Furthermore, the put-and-take method was used to control the weekly stocking rate, which was based on the forage accumulation rate. In addition, nitrogen fertilizer was applied three or four times during the Marandu grass growing season. Despite this, the adoption of this management strategy by farms can result in high animal performances. Our results suggest that after seven years of grazing management that a fixed pasture height that corresponds to the $95 \%$ light interception during the growing season, which results in greater $\mathrm{CP}$ concentration and leaf proportion for Marandu palisade grass. Therefore, obtaining higher animal performance.

\section{Conclusions}

The principal component analysis revealed that weather-related variables had a strong effect on the structure and nutritive value of the sward. The canonical correlation analysis showed that rainfall was the main variable explaining differences in structure and nutritive value. Greenhouse gas emissions from the soil and animals were controlled by climatic variables and, to a lesser extent, by grazing intensity.

Sward height had clear effects on sward structure, nutritive value, and animal performance. Based on the data of nutritive value, animal production per area, and greenhouse gas emissions, the sward height of $25 \mathrm{~cm}$ is the most visible way of obtaining greater animal performance and sustainability per area using Marandu palisade grass and continuous stocking.

Further studies should quantify the interactions between $\mathrm{N}$ fertilization and sward height as well as on the GHG emissions from fertilized grazed grasslands. These data could form the basis for further research evaluating the potential of managing the sward height of Marandu palisade grass to achieve sustainable intensification in forage-based beef cattle production.

Supplementary Materials: The following are available online at http://www.mdpi.com/2073-4395/10/11/1750/s1. Supplementary information SI: Source of data

Author Contributions: R.A.R. and A.C.R., conceptualization; A.d.S.C., D.R.C., R.P.B., M.V.A., A.A.O., J.F.W.K., and L.d.F.B., data collection; A.d.S.C., F.O., and A.C.R. data analysis; A.d.S.C., A.C.R., and R.A.R. writing-original preparation, review, and editing. All authors have read and agreed to the published version of the manuscript.

Funding: This research was funded by the Fundação de Amparo à Pesquisa do Estado de São Paulo (Fapesp grant numbers 2015/16631-5, 2017/11274-5, 2012/06718-8, 2012/20264-0, 2011/00060-8, and 2010/09564-6) and Conselho Nacional de Desenvolvimento Científico e Tecnológico (CNPq grant number 431713/2018-9). The research and associated scholarships were also funded by the Conselho Nacional de Desenvolvimento Científico e Tecnológico (CNPq) and the Comissão de Aperfeiçoamento de Pessoal de Nível Superior (CAPES).

Acknowledgments: Special thanks are given to the members of UnespFor for their contributions during the trials and insightful science discussions. We thank the staff of the forage and pasture sector of São Paulo State University (Jaboticabal). In addition, we thank Dennis Poppi and the anonymous reviewers for their helpful suggestions for improving the manuscript.

Conflicts of Interest: We declare that we have no conflict of interest.

\section{References}

1. Phelps, L.N.; Kaplan, J.O. Land use for animal production in global change studies: Defining and characterizing a framework. Glob. Chang. Biol. 2017, 23, 4457-4471. [CrossRef]

2. Cardoso, A.S.; Barbero, R.P.; Romanzini, E.P.; Teobaldo, R.W.; Ongaratto, F.; Fernandes, M.H.M.R.; Ruggieri, A.C.; Reis, R.A. Intensification: A key strategy to achieve great animal and environmental beef cattle production sustainability in Brachiaria grasslands. Sustainability 2020, 12, 6656. [CrossRef]

3. Raposo, E.; Brito, L.F.; Janusckiewicz, E.R.; Oliveira, L.F.; Versuti, J.; Assumpção, F.M.; Cardoso, A.S.; Seniscalchi, D.; Delevatti, L.M.; Malheiros, E.B.; et al. Greenhouse gases emissions from tropical grasslands affected by nitrogen fertilizer management. Agron. J. 2020, 112. [CrossRef] 
4. Lima, D.M.; Abdalla Filho, A.L.; Lima, P.D.M.T.; Sakita, G.Z.; McManus, C.; Abdalla, A.L.; Louvandini, H. Morphological characteristics, nutritive quality, and methane production of tropical grasses in Brazil. Pesq. Agropec. Bras. 2018, 53, 323-331. [CrossRef]

5. $\quad$ Euclides, V.P.B.; Valle, C.B.; Macedo, M.C.M.; Almeida, R.G.D.; Montagner, D.B.; Barbosa, R.A. Brazilian scientific progress in pasture research during the first decade of XXI century. Rev. Bras. Zootecn. 2010, 39, 151-168. [CrossRef]

6. Rudel, T.K.; Paul, B.; White, D.; Rao, I.M.; Van Der Hoek, R.; Castro, A.; Peters, M. LivestockPlus: Forages, sustainable intensification, and food security in the tropics. Ambio 2015, 44, 685-693. [CrossRef]

7. Euclides, V.P.B.; Euclides Filho, K.; Arruda, Z.D.; Figueiredo, G.D. Desempenho de novilhos em pastagens de Brachiaria decumbens submetidos a diferentes regimes alimentares. Rev. Bras. Zootec. 1998, 27, 246-254.

8. Pedreira, B.C.; Pedreira, C.G.S.; da Silva, S.C. Estrutura do dossel e acúmulo de forragem de Brachiaria brizantha cultivar Xaraés em resposta a estratégias de pastejo. Pesq. Agropec. Bras. 2007, 42, $281-287$. [CrossRef]

9. Giacomini, A.A.; Silva, S.C.D.; Sarmento, D.O.D.L.; Zeferino, C.V.; Souza Júnior, S.J.; Trindade, J.K.D.; Nascimento Júnior, D.D. Growth of Marandu palisadegrass subjected to strategies of intermittent stocking. Sci. Agric. 2009, 66, 733-741. [CrossRef]

10. Delevatti, L.M.; Cardoso, A.S.; Barbero, R.P.; Leite, R.G.; Romanzini, E.P.; Ruggieri, A.; Reis, R.A. Effect of nitrogen application rate on yield, forage quality, and animal performance in a tropical pasture. Sci. Rep. 2019, 9, 7596. [CrossRef]

11. Berça, A.S.; Cardoso, A.S.; Longhini, V.Z.; Tedeschi, L.O.; Boddey, R.M.; Berndt, A.; Reis, R.A.; Ruggieri, A.C. Methane production and nitrogen balance of dairy heifers grazing palisade grass $\mathrm{cv}$. Marandu alone or with forage peanut. J. Anim. Sci. 2019, 97, 4625-4634. [CrossRef]

12. Cardoso, S.A.; Brito, L.F.; Janusckiewicz, E.R.; Morgado, E.S.; Barbero, R.P.; Koscheck, J.F.W.; Reis, R.A.; Ruggieri, A.C. Impact of grazing intensity and seasons on greenhouse gas emissions in tropical grassland. Ecosystems 2017, 20, 845-859. [CrossRef]

13. Cardoso, A.S.; Oliveira, S.C.; Janusckiewicz, E.R.; Brito, L.F.; Morgado, E.S.; Reis, R.A.; Ruggieri, A.C. Effect of season on ammonia, nitrous oxide, and methane emission factors for beef cattle excreta and urea fertilizer applied to tropical pasture. Soil Till. Res. 2019, 194, 104341. [CrossRef]

14. Martin, C.; Morgavi, D.; Doreau, M. Methane mitigation in ruminants: From microbe to the farm scale. Animal 2010, 4, 351-365. [CrossRef]

15. Intergovernmental Panel on Climate Change (IPCC). 2019 Refinement to the 2006 IPCC Guidelines for National Greenhouse Gas Inventories. 2019. Available online: https://www.ipcc-nggip.iges.or.jp/public/ 2019rf/pdf/4_Volume4/19R_V4_Ch11_Soils_N2O_CO2.pdf (accessed on 19 July 2020).

16. IUSS. World Reference Base for Soil Resources, 1st ed.; World Soil Resources Reports; FAO: Rome, Italy, 2006.

17. Van Raij, B.; Cantarella, H.; Quaggio, J.A.; Furlani, A.M.C. Recomendações de Adubação e Calagem Para o Estado de São Paulo, 2nd ed.; IAC. Boletim Técnico, 100; Instituto Agronômico, Campinas: Brasilia, Brazil, 1997.

18. Mott, G.O.; Lucas, H.L. The design, conduct and interpretation of grazing trials on cultivated and improved pastures. In Proceedings of the 6th International Grassland Congress, Philadelphia, PA, USA, 17-23 August 1952; pp. 1380-1395.

19. Barbero, R.P.; Malheiros, E.B.; Araújo, T.L.R.; Nave, R.L.G.; Mulliniks, J.T.; Berchielli, T.T.; Reis, R.A. Combining Marandu grass grazing height and supplementation level to optimize growth and productivity of yearling bulls. Anim. Feed Sci. Technol. 2015, 209, 110-118. [CrossRef]

20. Casagrande, D.R.; Ruggieri, A.C.; Moretti, M.H.; Berchielli, T.T.; Vieira, B.R.; Roth, A.P.T.P.; Reis, R.A. Sward sward structure and performance of beef heifers under supplementation in Brachiaria brizantha $\mathrm{cv}$. Marandu pastures maintained with three grazing intensities in a continuous stocking system. Rev. Bras. Zootecn. 2011, 40, 2074-2082. [CrossRef]

21. Barbero, R.P.; Malheiros, E.B.; Nave, R.L.; Mulliniks, J.T.; Delevatti, L.M.; Koscheck, J.F.; Ruggieri, A.C.; Reis, R.A. Influence of post-weaning management system during the finishing phase on grasslands or feedlot on aiming to improvement of the beef cattle production. Agric. Syst. 2017, 153, 23-31. [CrossRef] 
22. Barre, P.; Turner, L.B.; Escobar-Gutiérrez, A.J. Leaf length variation in perennial forage grasses. Agriculture 2015, 5, 682-696. [CrossRef]

23. Calvano, M.P.C.A.; Euclides, V.P.B.; Montagner, D.B.; Lempp, B.; Difante, G.S.; Flores, R.S.; Galbeiro, S. Perfilhamento e acúmulo de forragem do capim-marandu submetido a diferentes intensidades de pastejo. Ceres 2011, 58, 781-789. [CrossRef]

24. Nunes, S.G.; Boock, A.; Penteado, M.D.O.; Gomes, D.T. Brachiaria Brizantha Cv. Marandu, 1st ed.; Embrapa Gado de Corte, Documentos (INFOTECA-E): Campo Grande, Brazil, 1984.

25. Poppi, D.P.; McLennan, S.R.; Bediye, S.; Vega, A.; Zorrilla-Rios, J. Forage quality: Strategies for increasing nutritive value of forages. In International Grassland Congress; Buchanan-Smith, J.G., Bailey, L.D., McCaughey, P., Eds.; Winnipeg \& Saskatoon: Winnipeg, MB, Canada, 1997.

26. Magalhães, J.A.; Carneiro, M.S.S.; Andrade, A.C.; Pereira, E.S.; Rodrigues, B.H.N.; Costa, N.L.; Townsend, C.R. Bromatological composition the Marandu grass under effect of different irrigation and nitrogen fertilization. Semina Ciênc. Agrár. 2015, 36, 933-942.

27. Araújo, R.A.D.; Rodrigues, R.C.; Costa, C.D.S.; Santos, F.N.S.; Costa, F.O.; Silva, I.R.D.; Rodrigues, M.M. Chemical composition and bromatologic degradability in situ of Marandu grass in silvopastoral systems formed by babassu and monoculture systems. Rev. Bras. Saúde Prod. Anim. 2016, 17, 401-412. [CrossRef]

28. McRoberts, K.C.; Parsons, D.; Ketterings, Q.M.; Hai, T.T.; Quan, N.H.; Ba, N.X.; Cherney, D.J.R. Urea and composted cattle manure affect forage yield and nutritive value in sandy soils of south-central Vietnam. Grass Forage Sci. 2017, 73, 132-145. [CrossRef]

29. Da Silva, S.C.; Sbrissia, A.F.; Pereira, L.E.T. Ecophysiology of C4 forage grasses-understanding plant growth for optimizing their use and management. Agriculture 2015, 5, 598-625. [CrossRef]

30. Hongyu, K.S.; Sandanielo's, V.L.M.; Oliveira Junior, G.J. Análise de Componentes Principais: Resumo teórico, aplicação e interpretação. Eng. Sci. 2015, 1, 83-90. [CrossRef]

31. Larsen, K.S.; Andresen, L.C.; Beier, C.; Jonasson, S.; Albert, K.R.; Ambus, P.E.R.; Ibrom, A. Reduced N cycling in response to elevated $\mathrm{CO}_{2}$, warming, and drought in a Danish heathland: Synthesizing results of the Climaite project after two years of treatments. Glob. Chang. Biol. 2011, 17, 1884-1899. [CrossRef]

32. $\mathrm{Xu}, \mathrm{Z} . \mathrm{Z}$.; Zhou, G.S. Combined effects of water stress and high temperature on photosynthesis, nitrogen metabolism and lipid peroxidation of a perennial grass. Leymus Chinensis Planta 2006, 224, 1080-1090. [CrossRef]

33. Erice, G.; Irigoyen, J.J.; Pérez, P.; Martínez-Carrasco, R.; Sánchez-Díaz, M. Effect of elevated $\mathrm{CO}_{2}$, temperature and drought on photosynthesis of nodulated alfalfa during a cutting regrowth cycle. Physiol. Plantarum 2006, 126, 458-468. [CrossRef]

34. Abd-Elgawad, M. Yield losses by phytonematodes: Challenges and opportunities with special reference to Egypt. Egypt. J. Agronematol. 2014, 13, 75-94. [CrossRef]

35. Kill-Silveira, R.; Jangarelli, M. How the calving order of cows affects the performance of Nellore calves. Acta Sci. Anim. Sci. 2018, 40, e34519. [CrossRef]

36. Underwood, K.R.; Tong, J.F.; Price, P.L.; Roberts, A.J.; Grings, E.E.; Hess, B.W.; Means, W.J.; Du, M. Nutrition during mid to late gestation affects growth, adipose tissue deposition, and tenderness in cross-bred beef steers. Meat Sci. 2010, 86, 588-593. [CrossRef]

37. Greenwood, P.L.; Cafe, L.M.; Hearnshaw, H.; Hennessy, D.W. Consequences of nutrition and growth retardation early in life for growth and composition of cattle and eating quality of beef. RAAN Aus. 2015, 15, 183-195.

38. Waldo, D.R.; Jorgensen, N.A. Forages for high animal production: Nutritional factors and effects of conservation. J. Dairy Sci. 1981, 64, 1207-1229. [CrossRef]

39. Poppi, D.P.; Hughes, T.P.; L'Huillier, P.J. Intake of Pasture by Grazing Ruminants. Livestock Feeding on Pasture; Hamilton Publishing: Hamilton, New Zealand, 1987; pp. 55-64.

40. McMeniman, J.P.; Defoor, P.J.; Galyean, M.L. Evaluation of the National Research Council (1996) dry matter intake prediction equations and relationships between intake and performance by feedlot cattle. J. Anim. Sci. 2009, 87, 1138-1146. [CrossRef] 
41. Tóth, E.; Deák, B.; Valkó, O.; Kelemen, A.; Miglécz, T.; Tóthmérész, B.; Török, P. Livestock type is more crucial than grazing intensity: Traditional cattle and sheep grazing in short-grass steppes. Land Degrad. Dev. 2018, 29, 231-239. [CrossRef]

42. Nave, R.L.G.; Sulc, R.M.; Barker, D.J. Relationships of forage nutritive value to cool-season grass canopy characteristics. Crop. Sci. 2013, 53, 341-348. [CrossRef]

43. Vieira, B.R.; Azenha, M.V.; Casagrande, D.R.; Costa, D.F.A.; Ruggieri, A.C.; Berchielli, T.T.; Reis, R.A. Ingestive behavior of supplemented Nellore heifers grazing palisade grass pastures managed with different sward heights. Anim. Sci. J. 2017, 88, 696-704. [CrossRef]

44. Carvalho, P.C.F.; Moraes, A. Comportamento ingestivo de ruminantes: Bases para o manejo sustentável do pasto. In Simpósio sobre Manejo Sustentável em Pastagem; Cecato, U., Barbosa, M.A.A.F., Galbeiro, S., Paris, W., Grecco, F.C.A.R., Soares Filho, C.V., Teixeira, S., Eds.; EdUEM: Maringá, Brazil, 2005; pp. 1-20.

45. Cardoso, A.S.; Berndt, A.; Leytem, A.; Alves, B.J.; Carvalho, I.D.N.D.; Soares, L.H.D.B.; Urquiaga, S.; Boddey, R.M. Impact of the intensification of beef production in Brazil on greenhouse gas emissions and land use. Agric. Syst. 2016, 143, 86-96. [CrossRef]

46. Sauvant, D.; Giger-Reverdin, S. Modélisation des interactions digestives et de la production de méthane. Inra Prod. Anim. 2009, 22, 375-384. [CrossRef]

47. José Neto, A.; Messana, J.D.; Granja-Salcedo, Y.T.; Castagnino, P.S.; Fiorentini, G.; Reis, R.A.; Berchielli, T.T. Effect of starch level in supplement with or without oil source on diet and apparent digestibility, rumen fermentation and microbial population of Nellore steers grazing tropical grass. Livest. Sci. 2017, 202, 171-179. [CrossRef]

48. Meister, N.C.; Cardoso, A.S.; Alari, F.O.; Lemos, N.L.S.; Frighetto, R.T.S.; Malheiros, E.B.; Reis, R.A.; Ruggieri, A.C. Effect of pasture management on enteric methane emissions from goats. Trop. Anim. Health Prod. 2021. just accepted.

49. Jones, F.M.; Phillips, F.A.; Naylor, T.; Mercer, N.B. Methane emissions from grazing Angus beef cows selected for divergent residual feed intake. Anim. Feed Sci. Technol. 2011, 166, 302-307. [CrossRef]

50. Barrière, Y.; Laperche, A.; Barrot, L.; Aurel, G.; Briand, M.; Jouanin, L. QTL analysis of lignification and cell wall digestibility in the Bay- $0 \times$ Shahdara RIL progeny of Arabidopsis thaliana as a model system for forage plants. Plant. Sci. 2005, 168, 1235-1245. [CrossRef]

51. Intergovernmental Panel on Climate Change. Guidelines for National Greenhouse Gas Inventories. Greenhouse Gas Inventory Reference Manual 4. 2006. Available online: http://www.ipcc971nggip.iges.or.jp/ public/2006gl/vol4.html (accessed on 19 July 2020).

52. Carbone, M.S.; Still, C.J.; Ambrose, A.R.; Dawson, T.E.; Williams, A.P.; Boot, C.M.; Schaeffer, S.M.; Schimel, J.P. Seasonal and episodic moisture controls on plant and microbial contributions to soil respiration. Oecologia 2011, 167, 265-278. [CrossRef]

53. Cardoso, A.S.; Quintana, B.G.; Janusckiewicz, E.; Brito, L.F.; Morgado, E.D.S.; Reis, R.A.; Ruggieri, A.C. How do methane rates vary with soil moisture and compaction, $\mathrm{N}$ compound and rate, and dung addition in a tropical soil? Int. J. Biometeorol. 2019, 63, 1533-1540. [CrossRef]

54. Davidson, E.A.; Janssens, I.A.; Luo, Y. On the variability of respiration in terrestrial ecosystems: Moving beyond Q10. Glob. Chang. Biol. 2006, 12, 154-164. [CrossRef]

55. Pezzopane, J.R.M.; Santos, P.M.; Evangelista, S.R.M.; Bosi, C.; Cavalcante, A.C.R.; Bettiol, G.M.; Pellegrino, G.Q. Panicum maximum cv. Tanzânia: Climate trends and regional pasture production in Brazil. Grass Forage Sci. 2017, 72, 104-117. [CrossRef]

56. Jantalia, C.P.; Santos, H.P.; Urquiaga, S.; Boddey, R.M.; Alves, B.J. Fluxes of nitrous oxide from soil under different crop rotations and tillage systems in the South of Brazil. Nutr. Cycling Agroecosyst. 2008, 82, 161-173. [CrossRef]

57. Mazzetto, A.M.; Barneze, A.S.; Feigl, B.J.; Van-Groenigen, J.W.; Oenema, O.; Cerri, C.C. Temperature and moisture affect methane and nitrous oxide emission from bovine manure patches in tropical conditions. Soil Biol. Biochem. 2014, 76, 242-248. [CrossRef]

58. Bayer, C.; Gomes, J.; Zanatta, J.A.; Vieira, F.C.B.; Piccolo, M.C.; Dieckow, J.; Six, J. Soil nitrous oxide emissions as affected by long-term tillage, cropping systems and nitrogen fertilization in Southern Brazil. Soil Till. Res. 2015, 146, 213-222. [CrossRef] 
59. Ryden, J.C.; Lund, L.J. Nature and extent of directly measured denitrification losses from some irrigated vegetable crop production units 1. Soil Sci. Soc. Am. J. 1980, 44, 505-511. [CrossRef]

60. Geng, J.; Cheng, S.; Fang, H.; Yu, G.; Li, X.; Si, G.; Yu, G. Soil nitrate accumulation explains the nonlinear responses of soil $\mathrm{CO}_{2}$ and $\mathrm{CH}_{4}$ fluxes to nitrogen addition in a temperate needle-broadleaved mixed forest. Ecol. Indic. 2017, 79, 28-36. [CrossRef]

Publisher's Note: MDPI stays neutral with regard to jurisdictional claims in published maps and institutional affiliations.

(C) 2020 by the authors. Licensee MDPI, Basel, Switzerland. This article is an open access article distributed under the terms and conditions of the Creative Commons Attribution (CC BY) license (http://creativecommons.org/licenses/by/4.0/). 